\title{
IDENTIFIKASI PERMASALAHAN PERANCANGAN PROGRAM BIMBINGAN DAN KONSELING PADA GURU SMK DI KOTA YOGYAKARTA
}

\author{
Muh Farozin, Suwarjo, Budi Astuti, Khairi Bintani, Ade Syarifah, dan Shufiyanti Arfalah \\ Universitas Negeri Yogyakarta \\ Email: farozin@uny.ac.id
}

\begin{abstract}
Abstrak
Penelitian ini bertujuan untuk mengidentifikasi permasalahan perancangan program bimbingan dan konseling pada guru bimbingan dan konseling SMK di kota Yogyakarta meliputi: rasional, dasar hukum, visi dan misi, deskripsi kebutuhan, tujuan, komponen program, bidang layanan, rencana operasional, pengembangan tema/topik, evaluasi, pelaporan dan tindak lanjut, anggaran biaya, sarana prasarana,dan ekuivalensi jam layanan bimbingan dan konseling dengan jam mata pelajaran. Metode yang digunakan adalah deskriptif kuantitatif. Hasil penelitian diketahui bahwa pada proses perancangan program bimbingan dan konseling, guru bimbingan dan konseling mengalami permasalahan pada aspek: (1) evaluasi pelaporan dan tindak lanjut; (2) anggaran biaya; (3) sarana prasarana; serta (4) ekuivalensi jam layanan bimbingan dan konseling dengan mata pelajaran. Hasil penelitian ini dapat digunakan sebagai dasar penelitian lanjutan yang terkait dengan perancangan program bimbingan dan konseling terutama pada kesulitan pada aspek evaluasi, pelaporan dan tindak lanjut; anggaran biaya; sarana prasarana; dan ekuivalensi jam layanan bimbingan dan konseling dengan mata pelajaran.
\end{abstract}

Kata kunci: perancangan program bimbingan dan konseling, guru SMK

\section{IDENTIFICATION THE PROBLEM OF THE DESIGN OF THE GUIDANCE AND COUNSELLING PROGRAM'S OF SMK TEACHERS IN YOGYAKARTA}

\begin{abstract}
This research aims to identify the problems of the design of the program guidance and counseling on guidance and counselling teachers SMK in Yogyakarta include: rational, legal basis, its vision and mission, the description of the needs, objectives, program components, field service, operational plans, development themes/topics, evaluation, reporting and follow-up, budget costs, infrastructure, and equivalence of guidance and counselling service with hours of subjects. The method used is descriptive quantitative. The results of the research it is known that in the process of designing a program of guidance and counselling, guidance and counselling teachers experienced problems on aspects of: (1) evaluation of the reporting and follow-up; (2) cost budget; (3) infrastructure; and (4) the equivalence of guidance and counselling service with its subjects. The results of this research can be used as a basis for further research related to the design of the program guidance and counseling especially on trouble on aspects of evaluation, reporting and follow-up; cost budget; infrastructure; and equivalence of guidance and counselling service with its subjects.
\end{abstract}

Keywords: design of guidance and counseling programs, teachers SMK

\section{PENDAHULUAN}

Konselor merupakan salah satu kualifikasi pendidik yang sejajar dengan kualifikasi guru, dosen, pamong belajar, tutor, widyaiswara, fasilitator, dan instruktur dalam sistem pendidikan nasional (Undang-Undang No. 20 Tahun 2003 Pasal 1 Ayat 6). Sebagai salah satu kualifikasi pendidik, konselor memiliki keunikan dalam konteks tugas dan 
ekspektasi kinerja. Permendiknas Nomor 27 Tahun 2008 mengenai standar kualifikasi akademik dan kompetensi konselor menyebutkan bahwa sosok utuh kompetensi konselor mencakup kompetensi akademik dan profesional sebagai satu keutuhan. Konselor atau guru bimbingan dan konseling harus memiliki kompetensi profesional, salah satunya yaitu mampu merancang program bimbingan dan konseling yang terdiri dari:

(1) menganalisis kebutuhan peserta didik, (2) menyusun program bimbingan dan konseling yang berkelanjutan berdasarkan kebutuhan peserta didik secara komprehensif dengan pendekatan perkembangan, (3) menyusun rencana pelaksanaan program bimbingan dan konseling, dan (4) merencanakan sarana dan biaya penyelenggaraan program bimbingan dan konseling. Keempat kemampuan ini harus dimiliki semua guru bimbingan dan konseling atau konselor, termasuk guru bimbingan dan konseling atau konselor yang bertugas di SMK.

Program bimbingan dan konseling dalam modul Diklat Peningkatan Kompetensi Guru BK/Konselor SMP/MTs diartikan sebagai seperangkat kegiatan bimbingan dan konseling yang dirancang secara terencana, terorganisasi, terkoordinasi selama periode waktu tertentu dan dilakukan secara kait-mengait untuk mencapai tujuan (Kemendikbud, 2013:11). Program bimbingan dan konseling pada dasarnya memberikan bantuan kepada peserta didik agar dapat mengenal dirinya secara matang. Hal ini memungkinkan agar layanan bimbingan dan konseling dapat berjalan dengan baik dan peserta didik dapat memahami fungsi pelayanan bimbingan dan konseling. Upaya untuk mewujudkan itu semua, guru bimbingan dan konseling atau konselor di sekolah dituntut untuk menyusun suatu program bimbingan dan konseling dengan perencanaan yang matang, sehingga tujuan yang ingin dicapai sesuai dengan harapan dari pendidikan dan individu.

Perencanaan program bimbingan dan konseling merupakan hal yang sangat penting karena perencanaan program bimbingan dan konseling dirancang untuk mencapai tujuan. Tujuan dari bimbingan dan konseling adalah memaksimalkan potensi peserta didik dan membantu mengatasi permasalahan yang dihadapi oleh mereka. Program bimbingan dan konseling juga dibuat untuk membantu semua peserta didik mengembangkan potensi mereka melalui pemberian bantuan pembangunan dan bantuan khusus untuk individu menyangkut masalah pribadi, sosial, karir, atau kebutuhan pendidikan yang unik lainnya (Gysbers dan Henderson, 2012:140). Apabila program tidak direncanakan dengan baik maka bimbingan dan konseling di sekolah tidak akan terlaksana dengan lancar, efektif dan efisien, serta hasil-hasilnya tidak dapat dinilai dengan baik.

Penyusunan program bimbingan dan konseling merupakan suatu tolak ukur kinerja guru bimbingan dan konseling atau konselor sebelum melaksanakan kegiatan pelayanan. Hal ini karena dapat diprediksikan bahwa semakin tinggi pemahaman guru bimbingan dan konseling atau konselor tentang program dalam bimbingan dan konseling, maka layanan akan dilaksanakan secara tertib dan lengkap.

Keterampilan dalam menyusun program bimbingan dan konseling merupakan hal yang wajib dimiliki guru bimbingan dan konseling atau konselor, namun pada kenyataannya masih banyak guru bimbingan dan konseling yang mengalami permasalahan dalam menyusun program bimbingan dan konseling. Hal ini berdasarkan penelitian yang dilakukan oleh Mare Asia Fajaryanti (2013) tentang identifikasi permasalahan pelaksanaan layanan bimbingan dan konseling di SD Muhammadiyah Mutihan Wates Kulon Progo yang meliputi tahap persiapan, proses pelaksanaan, evaluasi, dan tindak lanjut. Hasil penelitian pada tahap persiapan menyebutkan bahwa permasalahan tahap persiapan sebesar $55,56 \%$ dengan aspek tertinggi pada penyusunan satuan layanan, penyusunan 
satuan pendukung, dan pemahaman guru tentang bimbingan dan konseling.

Hal yang senada juga terungkap dari hasil penelitian yang dilakukan oleh Suranata dan Dewi Harum (Tjok Rai Partadjaja, dkk, 2012:3) yang menyebutkan bahwa $65 \%$ guru bimbingan dan konseling SMP dan SMU di Sukawati Gianyar belum mampu menyusun rencana pelaksanaan layanan bimbingan dan konseling (RPLBK) yang sesuai dengan kebutuhan peserta didik terhadap pelayanan bimbingan dan konseling. Terungkap juga dari hasil penelitian yang dilakukan Aan Purwanto, Muswardi Rosra, dan Yusmansyah (2014) mengenai analisis kinerja guru bimbingan dan konseling dalam penyusunan program bimbingan dan konseling. Hasil penelitian menunjukkan bahwa kinerja guru bimbingan dan konseling dalam penyusunan program bimbingan dan konseling kurang baik dikarenakan dalam menyusun program bimbingan dan konseling masih terdapat guru bimbingan dan konseling yang tidak melakukan analisis terhadap setiap aspek penyusunan program.

Ketiga penelitian tersebut memberikan informasi mengenai masih kurangnya kemampuan guru bimbingan dan konseling atau konselor dalam menyusun program bimbingan dan konseling, baik dalam hal menganalisis kebutuhan konseli, menyusun program bimbingan dan konseling yang berkelanjutan berdasarkan kebutuhan peserta didik secara komprehensif dengan pendekatan perkembangan, menyusun rencana pelaksanaan program bimbingan dan konseling, maupun dalam merencanakan sarana dan biaya penyelenggaraan program bimbingan dan konseling. Untuk membantu guru bimbingan dan konseling atau konselor mengatasi hal tersebut diperlukan identifikasi yang lebih mendalam mengenai permasalahan-permasalahan dalam perancangan program bimbingan dan konseling. Oleh karena itu, peneliti melakukan penelitian mengenai identifikasi permasalahan perancangan program bimbingan dan konseling di sekolah pada guru bimbingan dan konseling SMK di kota Yogyakarta.

Identifikasi permasalahan perancangan program bimbingan dan konseling yang dialami guru bimbingan dan konseling SMK yang akan diteliti mencakup rasional, dasar hukum, visi dan misi, deskripsi kebutuhan, tujuan, komponen program, bidang layanan, rencana operasional, pengembangan tema/topik, evaluasi, pelaporan dan tindak lanjut, anggaran biaya, sarana prasarana,dan ekuivalensi jam layanan bimbingan dan konseling dengan jam mata pelajaran.

Manfaat yang diharapkan dari penelitian ini secara teoritis diharapkan mampu memberikan informasi yang tepat serta dapat memberikan pemecahan terhadap permasalahan penyusunan program bimbingan dan konseling bagi guru bimbingan dan konseling SMK. Sedangkan manfaat praktis dari hasil penelitian ini yaitu bisa diaplikasikan dan dimanfaatkan dalam konteks yang lebih luas, di antaranya: bagi guru bimbingan dan konseling, hasil penelitian bermanfaat sebagai acuan untuk evaluasi diri sehingga dalam penyusunan program bimbingan dan konseling selanjutnya menjadi lebih baik. Bagi sekolah, hasil penelitian ini diharapkan mampu menjadi bahan pertimbangan pihak sekolah dalam mendukung kegiatan dan program guru bimbingan dan konseling yang ideal.

\section{METODE \\ Jenis penelitian}

Penelitian ini menggunakan pendekatan deskriptif kuantitatif dalam bentuk angka-angka persentase yang mendeskripsikan atau menggambarkan keadaan yang ada di lapangan mengenai permasalahan dalam menyusun program bimbingan dan konseling sebagaimana adanya tanpa membuat suatu perbandingan dengan variabel lain ataupun memberikan perlakuan kepada variabel yang diamati. 
Waktu dan Tempat Penelitian

Penelitian ini dilaksanakan pada bulan Juni-Oktober 2016. Lokasi penelitian berada di SMK se-Kota Yogyakarta.

\section{Subyek Penelitian}

Subjek penelitian ini adalah guru bimbingan dan konseling SMK se-Kota Yogyakarta yang berjumlah 46 guru dari 16 sekolah baik negeri maupun swasta berdasarkan data dari Dinas Pendidikan Kota Yogyakarta.

\section{Variabel Penelitian}

Variabel dalam penelitian ini adalah permasalahan penyusunan program BK yang terdiri dari aspek-aspek perancangan program bimbingan dan konseling sesuai dengan Permendikbud No. 111 tahun 2014 dan penambahan aspek berdasarkan hasil kajian peneliti. Aspek-aspek tersebut,yaitu rasional, dasar hukum, visi dan misi, deskripsi kebutuhan, tujuan, komponen program, bidang layanan, rencana operasional, pengembangan tema atau topik, evaluasi, pelaporan dan tindak lanjut, anggaran biaya, sarana prasarana dan ekuivalensi jam layanan bimbingan dan konseling dengan jam mata pelajaran.

Data, Instrumen, dan Teknik Pengumpulan Data

Penelitian ini menggunakan metode dan instrumen berupa angket yang dibagi menjadi dua bagian. Tipe pertanyaan dalam angket penelitian ini menggunakan pertanyaan tertutup mengenai permasalahan perancangan program bimbingan dan konseling. Jenis angket yang digunakan yaitu check list dengan memilih salah satu dari alternatif jawaban yang disediakan. Ada dua bentuk angket yang disediakan, yaitu bagian I merupakan angket yang menanyakan tentang kepemilikan yang berhubungan dengan perancangan program bimbingan dan konseling dengan pilihan jawaban yatidak, sedangkan bagian II menanyakan tentang pemahaman, keterampilan, keadaan kepemilikan yang berhubungan dengan perancangan program bimbingan dan konseling dengan lima pilihan jawaban yang disediakan (dapat dilihat pada Tabel $1)$.

\section{Teknik Analisis Data Penelitian}

Penelitian ini teknik analisis data yang dilakukan adalah dengan menghitung jumlah responden yang memilih permasalahan per item pertanyaan sesuai dengan pilihan jawaban yang disediakan. Kemudian dihitung jumlah item tiap kelompok masalah dan jumlah subjek yang memilih dalam tiap item kelompok masalah. Jawaban yang diberikan responden memiliki skor yang berbedabeda sesuai dengan tabel di bawah ini:

Tabel 1. Jenis Pertanyaan, Pilihan Jawaban, dan Skor pada Angket

\begin{tabular}{|c|c|c|c|}
\hline No & Angket & Pilihan Jawaban & Skor \\
\hline \multirow[t]{3}{*}{1.} & Bagian I & & \\
\hline & Kepemilikan yang berhubungan & Ya & 2 \\
\hline & & Tidak & 1 \\
\hline \multirow[t]{11}{*}{2.} & Bagian II & & \\
\hline & a. Pemahaman mengenai & Sangat Memahami (SM) & 5 \\
\hline & penyusunan program BK & Memahami (M) & 4 \\
\hline & & Cukup Memahami (CM) & 3 \\
\hline & & Kurang Memahami (KM) & 2 \\
\hline & & Tidak Memahami (TM) & 1 \\
\hline & b. Keterampilan dalam menyusun & Sangat Terampil (ST) & 5 \\
\hline & program $\mathrm{BK}$ & Terampil (T) & 4 \\
\hline & & Cukup Terampil (CT) & 3 \\
\hline & & Kurang Terampil (KT) & 2 \\
\hline & & Tidak Terampil (TT) & 1 \\
\hline
\end{tabular}


c. Keadaan kepemilikan yang berhubungan dengan penyusunan program BK
Sangat Baik (SB) 5

Baik (B) 4

Cukup Baik (CB) 3

Kurang Baik (KB) 2

Langkah selanjutnya setelah menghitung jumlah subjek/populasi, jumlah item pada tiap kelompok masalah sesuai dengan tabel skor, menghitung subjek yang memilih pada tiap kelompok masalah, adalah dihitung persentasenya. Berikut rumus persentase:

$$
\text { Persentase }=\left(\frac{\sum n}{N m}\right) \times 100 \%
$$

Keterangan:

$\mathrm{N}$ : Jumlah subjek/populasi

$\mathrm{m}$ : Jumlah item pada tiap kelompok masalah

$\sum \mathrm{n}:$ Jumlah subjek yang memilih pada tiap kelompok masalah

$\%$ : Persentase

Untuk memudahkan dalam menganalisis, peneliti hanya mengambil permasalahan untuk angket bagian I dengan persentase di atas 50\%. Hal ini diasumsikan bahwa guru bimbingan dan konseling tidak memiliki aspek-aspek yang dibutuhkan atau dipandang perlu dalam perancangan program bimbingan dan konseling. Sementara itu, persentase di bawah $50 \%$ diasumsikan masih dapat ditoleransi apabila guru tidak memiliki aspek-aspek tersebut dalam perancangan program bimbingan dan konseling. Pada bagian II, peneliti menggunakan norma di atas $20 \%$ untuk menganalisis permasalahan penyusunan program bimbingan dan konseling yang dimiliki guru bimbingan dan konseling pada aspek jawaban kurang dan tidak paham, kurang dan tidak terampil, serta keadaan kepemilikan yang kurang dan tidak baik. Norma 20\% merupakan jumlah dari persentase jawaban kurang dan tidak paham, kurang dan tidak terampil, serta keadaan kepemilikan yang kurang dan tidak baik. Hal ini diasumsikan bahwa guru bimbingan dan konseling memiliki permasalahan pada ranah pemahaman, keterampilan dan keadaan kepemilikan dalam aspek-aspek yang dibutuhkan atau dipandang perlu dalam perancangan program bimbingan dan konseling.

\section{PEMBAHASAN}

Untuk mengetahui permasalahan yang dialami guru BK dalam perancangan program bimbingan dan konseling, maka dilakukan analisis terhadap angket bagian I dan II yang meliputi rasional, dasar hukum, visi dan misi, deskripsi kebutuhan, tujuan, komponen program, bidang layanan, rencana operasional, pengembangan tema atau topik, evaluasi, pelaporan dan tindak lanjut, anggaran biaya, sarana prasarana, dan ekuivalensi jam layanan bimbingan dan konseling dengan jam mata pelajaran. Berikut merupakan hasil angket bagian I. 
Tabel 2. Hasil Angket Bagian I

\begin{tabular}{|c|c|c|}
\hline No & Pertanyaan & $\begin{array}{c}\text { Guru BK } \\
\text { Tidak Memiliki } \\
(\%)\end{array}$ \\
\hline \multirow{7}{*}{1} & $\begin{array}{l}\text { Apakah di sekolah tempat Anda bekerja memiliki ruang kerja } \\
\text { berupa: }\end{array}$ & \\
\hline & a. Ruang konseling pustaka & 78,26 \\
\hline & b. Ruang bimbingan dan konseling kelompok & 47,83 \\
\hline & c. Ruang data BK & 45,65 \\
\hline & d. Ruang konseling individual & 19,57 \\
\hline & e. Ruang kerja khusus BK & 2,17 \\
\hline & f. Ruang tamu BK & 0,00 \\
\hline 2 & $\begin{array}{l}\text { Apakah Anda/sekolah memiliki software analisis instrumen } \\
\text { evaluasi program BK tersebut? }\end{array}$ & 67,39 \\
\hline 3 & $\begin{array}{l}\text { Apakah pihak sekolah memberikan dana yang cukup untuk } \\
\text { prasarana BK? }\end{array}$ & 43,48 \\
\hline 4 & $\begin{array}{l}\text { Apakah pihak sekolah memberikan dana yang cukup untuk } \\
\text { sarana BK? }\end{array}$ & 39,13 \\
\hline \multirow{6}{*}{5} & $\begin{array}{l}\text { Apakah di ruang BK tempat Anda bekerja memiliki fasilitas } \\
\text { penunjang berupa: }\end{array}$ & \\
\hline & a. Alat pengumpul data berupa tes & 36,96 \\
\hline & $\begin{array}{l}\text { b. Perangkat elektronik (komputer, LCD, TV, CD interaktif, } \\
\text { sound system) }\end{array}$ & 28,26 \\
\hline & c. Alat pengumpul data berupa non tes & 13,04 \\
\hline & d. Papan informasi BK & 4,35 \\
\hline & e. Almari & 2,17 \\
\hline 6 & Apakah Anda/sekolah memiliki instrumen evaluasi program BK & 32,61 \\
\hline 7 & $\begin{array}{l}\text { Apakah terdapat layanan internet yang dapat membantu anda } \\
\text { untuk mengembangkan tema atau topik materi layanan dalam } \\
\text { program BK? }\end{array}$ & 8,70 \\
\hline 8 & $\begin{array}{l}\text { Apakah terdapat kegiatan penunjang pengembangan tema atau } \\
\text { topik materi layanan BK yang diselenggarakan oleh pemerintah } \\
\text { (Dinas Pendidikan)? }\end{array}$ & 8,70 \\
\hline 9 & Apakah anda membuat rancangan evaluasi program BK? & 6,52 \\
\hline 10 & $\begin{array}{l}\text { Apakah tujuan program BK yang Anda rumuskan berdasarkan } \\
\text { deskripsi kebutuhan atau tujuan umum BK? }\end{array}$ & 2,17 \\
\hline
\end{tabular}

Dari tabel 2 di atas, dan analisis berdasarkan norma yang ditetapkan yaitu permasalahan di atas 50\%, maka dapat disimpulkan bahwa pada proses perancangan program bimbingan dan konseling, guru bimbingan dan konseling mengalami kesulitan pada aspek sarana prasarana serta evaluasi, pelaporan dan tindak lanjut. Hasil tersebut kemudian dianalisis bersamaan dengan hasil dari angket bagian II. Berikut tabel hasil angket bagian II: 
Tabel 3. Analisis Angket Bagian II

\begin{tabular}{|c|c|c|c|c|c|c|c|c|c|c|c|c|c|c|c|c|}
\hline \multirow{3}{*}{ No } & \multirow{3}{*}{ Aspek Program BK } & \multicolumn{15}{|c|}{ Ranah } \\
\hline & & \multicolumn{5}{|c|}{ Pemahaman (\%) } & \multicolumn{5}{|c|}{ Keterampilan (\%) } & \multicolumn{5}{|c|}{ Keadaan Kepemilikan (\%) } \\
\hline & & SM & $\mathbf{M}$ & $\mathbf{C M}$ & $\mathbf{K M}$ & TM & ST & $\mathbf{T}$ & CT & KT & TT & SB & B & CB & $\mathbf{K B}$ & TB \\
\hline 1 & $\begin{array}{l}\text { Perancangan program secara } \\
\text { umum }\end{array}$ & 4,35 & 54,35 & 36,96 & 4,35 & 0 & - & - & - & - & - & - & - & - & - & - \\
\hline 2 & Rasional & 4,08 & 51,09 & 39,40 & 5,43 & 0 & - & - & - & - & - & - & - & - & - & - \\
\hline 3 & Dasar hukum & 2,90 & 42,03 & 35,51 & 19,57 & 0 & - & - & - & - & - & - & - & - & - & - \\
\hline 4 & Visi dan misi & 7,61 & 73,37 & 18,48 & 0,54 & 0 & 0 & 26,09 & 58,70 & 15,22 & 0 & - & - & - & - & - \\
\hline 5 & Deskripsi kebutuhan & 5,07 & 60,51 & 27,54 & 6,88 & 0 & 0 & 36,96 & 50,00 & 9,42 & 3,62 & - & - & - & - & - \\
\hline 6 & Tujuan & 4,35 & 63,04 & 30,98 & 1,63 & 0 & 0 & 47,83 & 47,83 & 4,35 & 0 & - & - & - & - & - \\
\hline 7 & Komponen program & 5,43 & 59,78 & 30,80 & 3,99 & 0 & 0,87 & 43,91 & 48,70 & 6,52 & 0 & - & - & - & - & - \\
\hline 8 & Bidang Layanan & 8,07 & 66,46 & 24,84 & 0,62 & 0 & - & - & - & - & - & - & - & - & - & - \\
\hline 9 & Rencana oprasional & 1,98 & 48,81 & 38,34 & 10,87 & 0 & 1,45 & 38,41 & 47,83 & 12,32 & 0 & - & - & - & - & - \\
\hline 10 & $\begin{array}{l}\text { Pengembangan tema atau } \\
\text { topik }\end{array}$ & 0,62 & 61,80 & 32,61 & 4,97 & 0 & 0 & 62,32 & 31,88 & 5,80 & 0 & 1,63 & 56,52 & 36,96 & 4,35 & 0,54 \\
\hline 11 & $\begin{array}{l}\text { Evaluasi, pelaporan, tindak } \\
\text { lanjut }\end{array}$ & 0,54 & 38,04 & 45,65 & 13,59 & 2,17 & 0 & 21,30 & 48,70 & 26,52 & 3,48 & 6,52 & 23,91 & 34,78 & 27,17 & 7,61 \\
\hline 12 & Anggaran biaya & 0,87 & 26,96 & 57,39 & 14,78 & 0 & 0 & 21,74 & 52,17 & 26,09 & 0 & 0 & 26,09 & 54,35 & 19,57 & 0 \\
\hline 13 & Sarana prasarana & 1,90 & 56,79 & 32,34 & 8,97 & 0 & 0 & 21,74 & 54,35 & 23,91 & 0 & 0,36 & 41,85 & 35,33 & 9,60 & 12,86 \\
\hline 14 & $\begin{array}{l}\text { Ekuivalensi jam layanan BK } \\
\text { dengan jam mata pelajaran }\end{array}$ & 2,17 & 31,88 & 46,74 & 18,12 & 1,09 & 0 & 15,22 & 47,83 & 34,78 & 2,17 & - & - & - & - & - \\
\hline
\end{tabular}


Dari hasil angket bagian II di atas kemudian dianalisis berdasarkan norma yang ditetapkan, yaitu jumlah permasalahan di atas $20 \%$ untuk persentase jawaban kurang dan tidak paham, atau kurang dan tidak terampil, atau keadaan kepemilikan yang kurang dan tidak baik, maka dapat disimpulkan bahwa pada proses perancangan program bimbingan dan konseling guru bimbingan dan konseling mengalami permasalahan pada aspek ekuivalensi jam layanan bimbingan dan konseling dengan jam mata pelajaran ranah keterampilan sebesar $36,95 \%$, aspek evaluasi, pelaporan dan tindak lanjut pada ranah keterampilan sebesar 30\% dan ranah keadaan kepemilikan sebesar 29,18\%, aspek anggaran biaya ranah keterampilan sebesar 26,09\%, serta aspek sarana prasarana pada ranah keterampilan seesar $23,91 \%$ dan ranah keadaan kepemilikan sebesar $22,46 \%$.

Jika dipaparkan lebih lanjut mengenai permasalahan guru bimbingan dan konseling pada proses perancangan program bimbingan dan konseling yaitu pada aspek evaluasi, pelaporan dan tindak lanjut, anggaran biaya, sarana dan prasarana, serta ekuivalensi jam layanan bimbingan dan konseling dengan jam mata pelajaran dapat dilihat pada tabel 4 di bawah ini:

Tabel 4. Perancangan Program Bimbingan dan Konseling

\begin{tabular}{|c|c|c|c|c|c|c|}
\hline $\begin{array}{l}\mathbf{N} \\
\mathbf{0}\end{array}$ & Aspek & Ranah & Permasalahan & $\begin{array}{l}\text { Kurang } \\
\text { terampil/ku } \\
\text { rang baik }\end{array}$ & $\begin{array}{c}\text { Tidak } \\
\text { terampil/ti } \\
\text { dak baik }\end{array}$ & Jumlah \\
\hline \multirow[t]{7}{*}{1.} & $\begin{array}{l}\text { Evaluasi, } \\
\text { pelaporan dan }\end{array}$ & Keterampilan & $\begin{array}{l}\text { Keterampilan membuat rancangan evaluasi } \\
\text { program bimbingan dan konseling }\end{array}$ & $26,09 \%$ & $2,17 \%$ & $28,26 \%$ \\
\hline & tindak lanjut & & $\begin{array}{l}\text { Keterampilan membuat rancangan evaluasi } \\
\text { layanan bimbingan dan konseling }\end{array}$ & $21,74 \%$ & $2,17 \%$ & $23,9 \%$ \\
\hline & & & $\begin{array}{l}\text { Keterampilan membuat rancangan pelaporan } \\
\text { pelaksanaan program bimbingan dan konseling }\end{array}$ & $23,91 \%$ & $2,17 \%$ & $26,09 \%$ \\
\hline & & & $\begin{array}{l}\text { Keterampilan membuat rancangan rekomendasi } \\
\text { tindak lanjut pengembangan program bimbingan } \\
\text { dan konseling selanjutnya }\end{array}$ & $23,91 \%$ & $2,17 \%$ & $26,09 \%$ \\
\hline & & & $\begin{array}{l}\text { Keterampilan dalam menggunakan software } \\
\text { analisis instrument evaluasi program bimbingan } \\
\text { dan konseling }\end{array}$ & $36,96 \%$ & $8,70 \%$ & $45,66 \%$ \\
\hline & & $\begin{array}{l}\text { Keadaan } \\
\text { kepemilikan }\end{array}$ & $\begin{array}{l}\text { Kondisi instumen evaluasi program bimbingan } \\
\text { dan konseling }\end{array}$ & $19,57 \%$ & $6,52 \%$ & $26,09 \%$ \\
\hline & & & $\begin{array}{l}\text { Kondisi software analisis instrument evaluasi } \\
\text { program bimbingan dan konseling }\end{array}$ & $34,78 \%$ & $8,70 \%$ & $43,48 \%$ \\
\hline 2. & $\begin{array}{l}\text { Anggaran } \\
\text { biaya }\end{array}$ & Keterampilan & $\begin{array}{l}\text { Keterampilan membuat rencana anggaran biaya } \\
\text { operasional layanan bimbingan dan konseling dan } \\
\text { pengembangan profesi }\end{array}$ & $26,09 \%$ & $0 \%$ & $26,09 \%$ \\
\hline \multirow[t]{6}{*}{3.} & $\begin{array}{l}\text { Sarana dan } \\
\text { prasarana }\end{array}$ & Keterampilan & $\begin{array}{l}\text { Keterampilan dalam membuat rencana pengadaan } \\
\text { sarana dan prasarana bimbingan dan konseling }\end{array}$ & $23.91 \%$ & $0 \%$ & $23.91 \%$ \\
\hline & $\begin{array}{l}\text { bimbingan } \\
\text { dan konseling }\end{array}$ & $\begin{array}{l}\text { Keadaan } \\
\text { kepemilikan }\end{array}$ & $\begin{array}{l}\text { Dukungan warga sekolah dalam membuat rincian } \\
\text { sarana dan prasarana bimbingan dan konseling }\end{array}$ & $17,39 \%$ & $4,35 \%$ & $21,74 \%$ \\
\hline & & & $\begin{array}{l}\text { Kondisi ruang bimbingan dan konseling } \\
\text { kelompok }\end{array}$ & $28,26 \%$ & $19,57 \%$ & $47,83 \%$ \\
\hline & & & Kondisi ruang data bimbingan dan konseling & $10,87 \%$ & $19,67 \%$ & $30,43 \%$ \\
\hline & & & Kondisi ruang konseling pustaka & $34,78 \%$ & 28,26 & $63,04 \%$ \\
\hline & & & Kondisi alat pengumpul data berupa tes & $0 \%$ & $28,26 \%$ & $28,26 \%$ \\
\hline 4. & $\begin{array}{l}\text { Ekuivalensi } \\
\text { jam layanan } \\
\text { bimbingan } \\
\text { dan konseling } \\
\text { dengan jam } \\
\text { mata pelajaran }\end{array}$ & Keterampilan & $\begin{array}{l}\text { Keterampilan dalam membuat ekuivalensi jam } \\
\text { layanan bimbingan dan konseling dengan jam } \\
\text { mata pelajaran }\end{array}$ & $34,78 \%$ & $2,17 \%$ & $36,96 \%$ \\
\hline
\end{tabular}


Berdasarkan hasil analisis data angket bagian I dan II tersebut di atas dapat diketahui bahwa pada tahap perancangan program bimbingan dan konseling guru bimbingan dan konseling mengalami kesulitan pada aspek aspekevaluasi, pelaporan dan tindak lanjut; anggaran biaya; sarana prasarana; serta ekuivalensi jam layanan bimbingan dan konseling dengan mata pelajaran. Pada aspek evaluasi, pelaporan dan tindak lanjut, guru bimbingan dan konseling SMK mengalami permasalahan pada ranah keterampilan, kepemilikan dan keadaan kepemilikan. Pada aspek anggaran biaya, guru bimbingan dan konseling mengalami permasalahan pada ranah keterampilan. Pada aspek sarana dan prasarana bimbingan dan konseling, guru bimbingan dan konseling juga mengalami permasalahan pada aspek keterampilan, kepemilikan, dan keadaan kepemilikan. Selain itu guru bimbingan dan konseling juga mengalami permasalahan pada aspek ekuivalensi jam layanan bimbingan dan konseling dengan jam mata pelajaran ranah keterampilan.

Pada aspek evaluasi, pelaporan dan tindak lanjut, dapat diketahui bahwa $28,26 \%$ guru bimbingan dan konseling kurang dan tidak terampil dalam membuat rancangan evaluasi program bimbingan dan konseling, 23,9\% kurang dan tidak terampil membuat rancangan evaluasi layanan, 26,09\% kurang dan tidak terampil membuat rancangan pelaporan pelaksanaan program, 26,09\% kurang dan tidak terampil membuat rancangan rekomendasi tindak lanjut pengembangan program bimbingan dan konseling selanjutnya, serta $45,66 \%$ kurang dan tidak terampil menggunakan software analisis instrumen evaluasi program bimbingan dan konseling.

Permasalahan lain terkait dengan aspek evaluasi, pelaporan dan tindak lanjut tergambar dari kepemilikan di mana guru bimbingan dan konseling tidak memiliki software analisis instrumen evaluasi program sebesar $67,39 \%$. Selain itu kondisi instrumen evaluasi program bimbingan dan konseling 26,09\% dalam keadaan kurang dan tidak baik, serta software analisis instrumen evaluasi program bimbingan dan konseling $43,48 \%$ dalam kondisi kurang dan tidak baik.

Evaluasi, pelaporan dan tindak lanjut merupakan kegiatan penting yang harus dilakukan guru bimbingan dan konseling. Hasil evaluasi dapat dijadikan salah satu bentuk akuntabilitas layanan bimbingan dan konseling. Dalam hal ini Gysbers \& Henderson (2012:139) dan Tolley \& Rowland (Ipah Saripah, 2006:70) menyatakan bahwa dalam perancangan program dibutuhkan evaluasi terhadap keefektifan program bimbingan dan konseling. Senada dengan ahli lainnya, Gibson dan Mitchel (2011:579) menyatakan bahwa menghindari evaluasi sama saja mengatakan programnya memiliki kelemahan dan berpotensi gagal. Evaluasi bagi konselor di berbagai lingkup adalah proses vital bagi penyempurnaan profesionalitas, sebuah proses yang mengumpulkan data performa yang objektif berdasarkan analisis yang sistematis. Data ini digunakan untuk meningkatkan, memperbaiki, mengembangkan, menyempurnakan dan memperbarui performa profesionalnya.

Menurut Aip Badrujaman (2011:3-5) ketiadaan evaluasi membuat terjadinya pengulangan berbagai program bimbingan dan konseling yang tidak menarik, serta tidak dibutuhkan oleh siswa. Aip Badrujaman mengemukakan bahwa apabila guru bimbingan dan konseling dapat menunjukkan bukti bahwa program bimbingan dan konseling itu dibutuhkan dan harus ada, maka kepala sekolah akan mengeluarkan kebijakan yang berpihak pada guru bimbingan dan konseling. Bukti yang diberikan tentunya bukanlah bukti subjektif guru bimbingan dan konseling yang dapat saja kemudian dibantah oleh guru lain atau kepala sekolah. Bukti yang harus ditunjukkan haruslah bukti yang berasal dari sebuah proses evaluasi yang dapat dipertanggungjawabkan.

Evaluasi merupakan hal yang penting, bukan hanya fungsinya sebagai 
alat untuk membuat perbaikan, akan tetapi karena evaluasi juga merupakan ukuran akuntabilitas terhadap program, atau layanan pendidikan yang diberikan kepada siswa. Sejalan dengan pentingnya evaluasi dalam perbaikan layanan dan pengambilan keputusan, guru bimbingan dan konseling sebagai evaluator dituntut memiliki kemampuan dan keterampilan dalam memilih dan mendesain evaluasi terhadap layanan yang diselenggerakan kepada siswa. Meskipun penting, akan tetapi tuntutan menjadi evaluator sendiri terhadap program bimbingan konseling yang diselenggarakan, bukanlah hal yang mudah. Beberapa penelitian menunjukkan bahwa banyak guru bimbingan dan konseling tidak melakukan evaluasi terhadap program yang diselenggarakannya (Aip Badrujaman, 2011:6-7).

Kondisi di mana guru bimbingan dan konseling tidak melakukan evaluasi terhadap program yang diselenggarakan tentunya dipengaruhi oleh banyak faktor. Salah satu faktor yang mempengaruhi pelaksanaan evaluasi oleh guru bimbingan dan konseling adalah pengetahuan guru bimbingan dan konseling mengenai evaluasi program bimbingan dan konseling yang masih rendah. Penelitian yang dilakukan oleh Arifin tahun 2002 (Aip Badrujaman, 2011:8) mengenai pengetahuan evaluasi guru bimbingan dan konseling di Sulawesi Selatan, menunjukkan bahwa guru bimbingan dan konseling memiliki pengetahuan evaluasi yang rendah. Hal tersebut terlihat dari skor yang diperoleh responden dalam penelitian, di mana sebanyak $85,36 \%$ responden memiliki skor di bawah 12 (rentangan skor 0-24), sedangkan hanya $14,64 \%$ responden yang memperoleh skor di atas 12, secara keseluruhan rerata skor yang diperoleh responden adalah 8,69. Penelitian Gantina dkk (2011) memperkuat temuan Arifin mengenai rendahnya tingkat pengetahuan guru bimbingan dan konseling mengenai evaluasi program bimbingan dan konseling, faktor lain yang juga memberikan pengaruh pada pelaksanaan evaluasi program bimbingan konseling adalah komitmen guru bimbingan dan konseling itu sendiri dalam memberikan layanan program bimbingan konseling termasuk melaksanakan evaluasi di dalamnya.

Fenomena di atas, tentunya memberikan gambaran bahwa guru bimbingan konseling masih memiliki keterbatasan untuk melakukan evaluasi terhadap layanan yang mereka selenggarakan. Pada satu sisi mereka sadar bahwa melakukan evaluasi merupakan kegiatan yang menjadi kebutuhan mereka untuk dilakukan, akan tetapi di sisi yang lain, mereka kurang memiliki pengetahuan mengenai evaluasi program bimbingan konseling itu sendiri.

Rendahnya persentase guru bimbingan dan konseling yang melakukan evaluasi terhadap program bimbingan dan konseling yang diselenggarakannya, tentunya dapat memiliki dampak yang negatif bagi program bimbingan dan konseling itu sendiri. Dampak negatif tersebut dapat berupa ketiadaan informasi sebagai umpan balik yang seharusnya menjadi petunjuk berkenaan dengan kekuatan dan kelemahan program yang diselenggarakan. Selain itu, guru bimbingan dan konseling tidak dapat mengetahui secara pasti apakah tujuan program yang telah ditetapkan sudah tercapai. Ketiadaan evaluasi dapat berdampak pula guru bimbingan dan konseling mengulangi program yang sesungguhnya tidak menjadi kebutuhan siswa, serta tidak bersentuhan dengan permasalahan yang ada pada siswa. Permasalahan tersebut tentunya dapat menciptakan kondisi di mana program bimbingan dan konseling diselenggarakan akan tetapi permasalahan siswa tetap tinggi. Hal ini senada dengan pendapat Tohirin (2007:347-348) bahwa pelayanan bimbingan dan konseling merupakan suatu proses, sehingga untuk mengetahui keberhasilan proses tersebut perlu dilakukan evaluasi. Selain merupakan suatu proses, pelayanan bimbingan dan konseling merupakan kegiatan yang 
bertujuan sehingga untuk mengetahui tercapai tidaknya tujuan perlu dievaluasi.

Evaluasi program bimbingan dan konseling juga dilakukan untuk mengetahui apakah program bimbingan dan konseling yang dirumuskan telah membawa dampak atau hasil-hasil tertentu terhadap klien atau belum. Dengan perkataan lain, evaluasi program bimbingan dan konseling dilakukan untuk mengetahui keberhasilan proses, pencapaian tujuan juga untuk melakukan follow up misalnya untuk perbaikan program bimbingan dan konseling, sehingga pada gilirannya akan dapat meningkatkan mutu atau kualitas pelayanan bimbingan dan konseling itu sendiri.

Permasalahan lain yang teridentifikasi terletak pada anggaran biaya, di mana guru bimbingan dan konseling kurang terampil dalam membuat rencana anggaran biaya operasional layanan bimbingan dan konseling dan pengembangan profesi dengan persentase sebesar 26,09\%. Kemudian pada aspek sarana dan prasarana, $23,91 \%$ guru bimbingan dan konseling kurang terampil dalam membuat rencana pengadaan sarana prasarana bimbingan dan konseling di sekolah dan dukungan warga sekolah dalam membuat rincian sarana dan prasarana bimbingan dan konseling dalam keadaan kurang dan tidak baik sebesar 21,47\%. Padahal apabila dilihat dari kondisi yang ada terdapat $78,26 \%$ guru bimbingan dan konseling tidak memiliki ruang konseling pustaka. Selain itu kondisi ruang bimbingan dan konseling kelompok yang ada tercatat $47,83 \%$ dalam keadaan yang kurang dan tidak baik. Begitu pula dengan kondisi ruang data 30,43\% kurang dan tidak baik, ruang konseling pustaka $63,04 \%$ dalam kondisi kurang dan tidak baik, serta kondisi alat pengumpul data berupa tes juga dalam kondisi tidak baik sebesar 28,26\%.

Permasalahan mengenai anggaran biaya serta sarana dan prasarana bimbingan dan konseling perlu ditindaklanjuti, mengingat pendapat dari Achmad Juntika
N (2005:50) yang mengatakan bahwa fasilitas dan pembiayaan merupakan aspek penting yang harus diperhatikan dalam suatu program bimbingan. Adapun aspek pembiayaan memerlukan perhatian yang lebih serius karena dalam kenyataannya aspek tersebut merupakan salah satu faktor penghambat proses pelaksanaan layanan bimbingan dan konseling. Tanpa adanya fasilitas dan pembiayaan yang memadai, maka proses pelaksanaan program layanan bimbingan dan konseling cemderung mengalami hambatan.

Panduan operasional penyelenggaraan bimbingan dan konseling di SMK tahun 2016 mengisyaratkan rancangan kebutuhan sarana prasarana disesuaikan dengan dukungan kebijakan dan dana serta kemanfaatannya. Usulan dana yang dibutuhkan selama layanan bimbingan dan konseling agar terlihat rinciannya secara jelas dapat dilakukan sejalan dengan program bimbingan dan konseling secara keseluruhan. Pengajuan dana harus jelas rincian penggunaannya dapat juga berupa kesatuan dalam program yang diuraikan kebutuhan dana perkegiatan.

Senada dengan pendapat di atas, pentingnya membuat anggaran biaya serta pengadaan sarana prasarana dikuatkan dengan Peraturan Pemerintah No. 27 tahun 2008 tentang Standar Kualifikasi Akademik dan Kompetensi Konselor bahwa seorang konselor harus memiliki kompetensi professional point ke-13.4, yaitu seorang konselor atau guru bimbingan dan konseling harus memiliki kompetensi merencanakan sarana dan biaya penyelenggaraan program bimbingan dan konseling.

Permasalahan dalam perancangan penyusunan program bimbingan dan konseling lainnya adalah ekuivalensi jam layanan bimbingan dan konseling dengan jam mata pelajaran. Berdasarkan hasil penelitian tercatat bahwa $36,96 \%$ guru bimbingan dan konseling kurang dan tidak terampil dalam membuat ekuivalensi jam layanan bimbingan dan konseling dengan jam mata pelajaran. Ekuivalensi berisi penyetaraan kegiatan bimbingan dan 
konseling yang dilakukan dengan jumlah jam. Dalam Permendikbud No 111 Tahun 2014 disebutkan bahwa beban kerja seorang konselor atau guru bimbingan dan konseling adalah 150-160 peserta didik ekuivalen dengan 24 jam pembelajaran dengan perhitungan yang berbeda untuk setiap kegiatan yang dilakukan oleh guru bimbingan dan konseling.

Penyetaraan atau ekuivalensi jam layanan bimbingan dan konseling dengan jam mata pelajaranpenting untuk dilakukan karena kegiatan yang dilakukan oleh guru bimbingan dan konseling berbeda dengan guru mata pelajaran. Keterampilan mengekuivalensikan jam layanan bimbingan dan konseling dengan jam mata pelajaran perlu dilakukan untuk meningkatkan profesionalitas guru bimbingan dan konseling serta mempermudah dalam perhitungan kinerja guru bimbingan dan konseling jika disetarakan dengan jam mata pelajaran.

\section{PENUTUP}

\section{Simpulan}

Pada proses perancangan program bimbingan dan konseling, guru bimbingan dan konseling mengalami permasalahan pada aspek:(1) evaluasi pelaporan dan tindak lanjut yang meliputi keterampilan membuat rancangan evaluasi program, evaluasi layanan, pelaporan pelaksanaan program dan rekomendasi tindak lanjut, serta keterampilan menggunakan software analisis instrumen program bimbingan dan konseling, tidak memiliki software analisis instrumen evaluasi program, serta kondisi yang kurang dan tidak baik pada instrumen dan software analisis instrumen evaluasi program bimbingan dan konseling; (2) anggaran biaya, yaitu keterampilan membuat rencana anggaran biaya operasional layanan bimbingan dan konseling dan pengembangan profesi (3) sarana prasarana, meliputi keterampilan membuat rencana pengadaan sarana prasarana bimbingan dan konseling dan pada dukungan warga sekolah dalam membuat rincian sarana prasarana bimbingan dan konseling, tidak memiliki ruang konseling pustaka, kondisi ruang bimbingan dan konseling kelompok, ruang data, ruang konseling pustaka, dan kondisi fasilitas penunjang yang berupa alat pengumpul data berupa tes yang kurang dan tidak baik; serta (4) ekuivalensi jam layanan bimbingan dan konseling dengan mata pelajaran yaitu keterampilan membuat ekuvalensi jam layanan bimbingan dan konseling dengan jam mata pelajaran.

\section{Saran}

1. Sekolah

Sekolah dapat memberikan fasilitas dan aktif mengikutsertakan guru untuk mengikuti diklat, pelatihan, dan workshop mengenai keterampilan dalam menyusun program bimbingan dan konseling agar kompetensi guru bimbingan dan konseling dalam menyusun program bimbingan dan konseling dapat meningkat sehingga sikap profesional guru dapat lebih baik.

2. Guru bimbingan dan konseling

Guru bimbingan dan konseling harus aktif memperbaharui wawasan dan juga keterampilan yang menunjang profesinya sebagai seorang pendidik dengan mengikuti diklat, pelatihan dan juga workshop di luar sekolah dan pelatihan nasional. Sehingga hasil penelitian ini dapat digunakan sebagai bahan evaluasi bagi guru bimbingan dan konseling dalam mengetahui, memahami dan berupaya pada hal yang masih perlu dikembangkan oleh dirinya khususnya dalam penyusunan program bimbingan dan konseling SMK.

\section{Peneliti selanjutnya}

Hasil penelitian ini dapat digunakan sebagai dasar penelitian lanjutan yang terkait dengan perancangan program bimbingan dan konseling tentang kesulitan pada aspek evaluasi, pelaporan dan tindak lanjut; anggaran biaya; sarana prasarana; dan ekuivalensi jam layanan bimbingan dan konseling dengan mata pelajaran. 


\section{DAFTAR PUSTAKA}

Aan Purwanto, Muswardi Rosra, dan Yusmansyah. (2014). Analisis Kinerja Guru Pembimbing dalam Penyususnan Program Bimbingan dan Konseling. Universitas Lampung.

Achmad Juntika Nurihasan. (2005). Strategi Layanan Bimbingan dan Konseling.

Bandung :Refika Aditama.

Aip, Badrujaman. (2011). Teori \& Aplikasi Evaluasi Program Bimbingan \& Konseling.Jakarta: PT Indeks.

Gantina, Komalasari, dkk. (2011). Asesmen Teknik Nontes dalam Perspektif BK Komprehensif.Jakarta: PT Indeks.

Gysbers, Norman C and Henderson, Patricia. (2012). Developing Managing Your School Guidance and Counseling Program (Fifth Edition). Alexandria: American Counseling Association.

Gibson, Robert and Mitchell Mariane. (2011). Introduction to counseling and guidance. New Jersey: Pearson Education Hall

Ipah Saripah. (2006). Program Bimbingan untuk Mengembangkan Perilaku Prososial Anak.Tesis. Program Pasca Sarjana UPI Bandung : tidak diterbitkan.

Kementerian Pendidikan dan Kebudayaan. (2013). Modul Diklat Peningkatan Kompetensi Guru BK/ Konselor SMP/ MTs: Implementasi Program Bimbingan dan Konseling dalam Kurikulum 2013.

Mare Asia Fajaryanti. (2013). Identifikasi Permasalahan Pelaksanaan Layanan Bimbingan dan Konseling di Sekolah Dasar Muhammadiyah Mutihan Wates Kulon Progo.

Menteri Pendidikan Nasional. (2008). Peraturan Menteri Pendidikan Nasional (Permendiknas) Republik Indonesia, Nomor 27, Tahun 2008, tentang Standar Kualifikasi Akademik dan Kompetensi Konselor.
Menteri Pendidikan Nasional. (2014). Peraturan Menteri Pendidikan dan Kebudayaan Republik Indonesia, Nomor 111, Tahun 2014, tentang Bimbingan dan Konseling Pada Pendidikan Dasar dan Pendidikan Menengah.

Republik Indonesia. (2003). Undangundang RI Nomor 20, Tahun 2003, tentang Sistem Pendidikan Nasional.

Tjok Rai Partadjaja, Ketut Suma, Kadek Suranata, Ni Made Sulastri. (2012). Laporan PPM: Pelatihan Penyusunan Rencana Pelayanan Konseling Berdasarkan Data AUM Pada Para Guru BK di Kecamatan Sukawati Gianyar. Unversitas Pendidikan Ganesa Singaraja.

Tohirin. (2007). Bimbingan dan Konseling di Sekolah dan Madrasah (Berbasis Integrasi). Jakarta: PT Raja Grafindo Persada. 